\title{
Comparison of Writing Anxiety and Writing Dispositions of Sixth, Seventh and Eighth Grade Students
}

\section{Rifat Ramazan Berk}

Res. Asst., Bayburt University, Faculty of Education, Turkish Education Department, Bayburt, Turkey, rifatberk@bayburt.edu.tr

\section{Emre Ünal}

Assoc. Prof., Niğde University, Faculty of Education, Primary Education Department, Niğde, Turkey,emreunal@nigde.edu.tr writing anxiety and dispositions and to examine to what extent they predict each other. The basis of this study is to determine whether writing disposition is the significant predictor of writing anxiety or not and whether students' grade levels and genders are significant predictor of writing anxiety and dispositions or not. The research was designed according to survey model. The study group, selected through simple sampling method, is made up of 860 students studying at $6^{\text {th }}, 7^{\text {th }}$ and $8^{\text {th }}$ grades in elementary schools of Şarkışla District, Sivas. While "Writing Anxiety Scale", adapted into Turkish by Özbay and Zorbay (2011), was administered to determine the study group's writing anxiety level, "Writing Disposition Scale", adapted into Turkish by İşeri and Ünal (2010), was used to determine the writing disposition level. At the end of the study, it was found that writing disposition is a significant predictor of writing anxiety and students' grade levels and genders are significant predictors of writing anxiety and dispositions. An education environment to create a strong writing disposition for students is recommended. Also, similar studies on different dimensions of the issue can be conducted.

Key Words: writing anxiety, writing disposition, writing skill, elementary school, writing

\section{INTRODUCTION}

Writing, one of the four basic language skills, is a means of narrating feelings, thoughts, desires and events through certain symbols in accordance with certain rules (Özbay, 2006). Sever (2004) referred to writing action as expressing one's senses, thoughts, plans and experiences through writing. 
Since writing is intertwined with mental processes, it contributes to the development of many skills. It helps to widen students' thoughts, organize their knowledge, use language, enrich their knowledge accumulation and develop their mental dictionaries (Güneş, 2013). In addition, it makes it easier to examine what is being thought by putting them on paper.

Today's technological developments are increasing the importance of improving writing skills. According to Özbay (2011), written communications in social life have gained importance due to technological advancements. Similarly, Yancey (2009) stated that humankind produced writing more than ever in the twenty-first century. Increase in platforms like instant messaging, forums, news coverage, social networks, social networking sites, blogs, e-mails and chat rooms have also increased the number of people who write. Written communication is undeniably spreading to every aspect of life.

In the literature, the researchers frequently voice that writing skill which has many benefits for students' cognitive and affective development is the most complex and most hard-won among the language skills (Karatay, 2011) and it is an ignored skill (Güneş, 2007; Karakoç Öztürk, 2012; Yaman, 2013;). The studies examining the written expression skill levels of students at different grade levels of elementary schools specify that students do not reach the targeted levels in the programs in terms of their written expression skills.

While reasons like using traditional teaching methods in Turkish classes (Aktaş \& Gündüz; 2004; Göçer, 2011; Ungan, 2007), test type exams (Aktaş \& Gündüz, 2004; Uçgun, 2011) and not giving necessary importance to the written expression course (Karatay, 2011; Ungan, 2007) are found to be among the reasons why students' writing skills cannot be improved, the scarcity of studies examining affective dimension of written expression process and effects of problems encountered in affective dimension of writing on students' writing skills are not paid attention to.

Although many researchers accepted that writing has an affective dimension (Daly \& Wilson, 1983; McLeod, 1987; Piazza \& Siebert, 2008; Smagorinsky \& Daigle; 2012), students' affective dispositions towards writing are not the subjects of many studies (Piazza \& Siebert, 2008). In this regard, writing anxiety and writing disposition (McClenny, 2010; Piazza \& Siebert, 2008; Smagorinsky \& Daigle; 2012) that are discussed in writing's affective dimension (Brand \& Powell, 1986; Hidi \& Boscolo, 2006; Mcleod, 1987) are among the subjects which have been studied on in our country recently (Baş \& Şahin, 2012; İşeri \& Ünal, 2010; İşeri \& Ünal, 2012; Karakaya \& Ülper, 2011; Karakoç Öztürk, 2012; Özbay \& Zorbaz, 2011; Tiryaki, 2012; Tüfekçioğlu, 2010; Yaman, 2010; Zorbaz, 2010).

Writing anxiety is an anxiety specific to writing that has been researched since 1975 (Daly and Miller, 1975a; 1975b). Examined with its various aspects by many researchers in many countries for nearly 40 years, it has become a subject that researchers have been doing research on in recent years. 
Writing anxiety is defined as the fear or anxiety regarding writing (Tighe, 1987). Writing anxiety, a reaction developed against writing, affectively manifests itself in sadness, anger and fear and physically in various cramps and sweating (Poff, 2004: 168 cited in Zorbaz, 2010).

It was found that this reaction developed against writing has negative effects on writing quality and writing success and has led to situations like avoiding and not wanting to write (Hettich, 1994; Matthews, 2001 cited in Zorbaz, 2010).

Writing anxiety affects students' attitudes, behaviors and written products. Summarizing the findings of the studies conducted by Daly and his colleagues until 1981, Reeves (1997) stated that individuals with high writing anxiety tended to choose careers that do not require any writing or require little writing, avoided courses and specialization on subjects that require daily writing and wrote very little outside the classroom. Reeves (1997) pointed out that these individuals were deprived of role models in terms of writing at home and school and in society and their motivation conditions varied. The findings also showed that the individuals with high writing anxiety were apt to get lower scores from oral ability exams, reading comprehension and university entrance standardized exams.

Disposition is a term used in philosophy, psychology -personality and personality development- (Katz, 1993; Thornton, 2006) and education literature. Changes made in teacher training in the US recently and new quality standards put into effect led to many discussions on the term "disposition".

Various definitions were made by many researchers to clarify the concept of the term disposition. Each definition made led to an increase in terminology regarding the term or new questions regarding disposition. Sing and Stoloff (2007) remark on giving a definition of the term "disposition" that everyone can agree on to be able to respond clearly to all these questions.

According to Piazza and Siebert (2008), dispositions are wide structures discussed under affective conditions like self-efficacy, interest and motivation individuals feel or sense while writing. According to Katz (1993), dispositions are frequently repeated behavior patterns that the individual consciously chooses without authority, pressure or coercion. Smith, Skarbek and Hursk (2005) argue that definition offered by Katz and Raths is the most effective and the most cited one among the definitions given to clarify the term disposition.

According to Katz and Rath (1985) attainment of a skill does not mean that the individual will use that skill or exhibit it. The individual's disposition regarding that skill needs to be strong, too. Da Ros Voseles \& Fowler Hugley (2007) mention that dispositions are sensitive to the settings and this should be kept in mind wile organizing educational settings.

Katz (1993, p. 5), based on Buss and Craik's definition of disposition as "summaries of act frequencies", claimed that if one frequently donates to charities, buys presents to family members or loans money to friends in need, that person can be said to have a 
disposition for being generous. Similarly, if a child asks questions frequently, examines the environment with curious eyes and if that child is constant in a learning or research activity, it can be said this child has a strong disposition to be curious.

In that case, given the examples on writing in the literature, we can mention that an individual having writing skills does not mean that that person has a strong disposition towards writing and that if an individual is observed to write consciously frequently and voluntarily without any pressure or reward, that person has strong disposition towards writing.

\section{Objectives of the Study}

The purpose of this study is to determine sixth, seventh and eighth grade students' writing anxiety and dispositions and to find out to what extent they predict each other. For this purpose, the answers to the following questions were sought:

- Are students' grade levels and genders significant predictors of writing disposition?

- Are students' grade levels and genders significant predictors of writing anxiety?

\section{METHOD}

\section{Research Design}

This study is designed according to survey model which aims to "describe an existing situation that happened in the past or is still happening" (Karasar, 1999: 77).

\section{Sample}

The sample of the study consisted of 860 students from 6th, 7th and 8th grade studying at Anafartalar Elementary School (62), Aşık Veysel Elementary School (87), Atatürk Elementary School (115), Cumhuriyet Elementary School (80), Doçent Doktor Abdüllatif Şener Elementary School (141), Kahraman Köseoğlu Elementary School (37), Mehmet Emin Tuna Elementary School (64), Milli Egemenlik Elementary School (89), Hürriyet Elementary School (87) and Şehit Tuncer Çeliker Boarding Elementary School (98) in Şarkışla district of the city of Sivas were selected through simple sampling method. Gender distribution of the study group is shown in table 1 . 
Table 1

Demographic data showing study group based on gender

\begin{tabular}{ccccc}
\hline \multicolumn{2}{c}{ Grade Level } & \multicolumn{2}{c}{ Gender } & Total \\
\hline \multirow{2}{*}{ Grade 6 } & $\mathrm{n}$ & 190 & 158 & 348 \\
& $\%$ & 22,1 & 18,4 & 40,5 \\
\multirow{4}{*}{ Grade 7} & $\mathrm{n}$ & 101 & 109 & 210 \\
& $\%$ & 11,7 & 12,7 & 24,4 \\
Grade 8 & $\mathrm{n}$ & 169 & 133 & 302 \\
& $\%$ & 19,7 & 15,5 & 35,1 \\
\multirow{2}{*}{ Total } & $\mathrm{n}$ & 460 & 400 & 860 \\
& $\%$ & 53,5 & 46,5 & 100 \\
\hline
\end{tabular}

According to Table 1,190 of the $3486^{\text {th }}$ grade students participating in the study are female and 158 of them are male. The numbers of female and male participants who study at $7^{\text {th }}$ grade are 110 and 109 respectively. Finally, 169 of the $3028^{\text {th }}$ grade students participating in the study are female while 133 of them are male.

\section{Data Collection and Analysis}

In the study, "Writing Anxiety Scale" and "Writing Disposition Scale" were used as data collection tools. The "Writing Anxiety Scale" developed by Daly and Miller (1975) and adapted into Turkish by Özbay and Zorbaz (2011) was administered with permission from the researchers. The original scale was a five-point Likert-type one including strongly agree, agree, don't know, disagree and strongly disagree choices and it was made up of 26 items.

During the scale's adaptation into Turkish process, changes were made on the $5^{\text {th }}, 18^{\text {th }}$ and $21^{\text {st }}$ items since there was not a separate writing or composition course other than the Turkish course in elementary schools. The scale was administered to middle school students. The findings obtained at the end of this 26-item scale's Turkish adaptation, and validity and reliability tests show that the 21 -item version of the scale can be administered in a valid and reliable way (Özbay \& Zorbaz, 2011: 44).

During the entry of the data obtained from the scale into the computer, while the items with positive statements $(1,4,5,7,8,13,16,18,21,22,24,25,26)$ were scored 1 point for "strongly agree", 2 points for "agree", 3 points for "undecided", 4 points for "disagree" and 5 points for "strongly disagree", the scoring was reversed for the items with negative statements $(2,3,6,9,10,11,12,14,15,17,19,20,23)$ and these items were scored 5 points for "strongly agree", 4 points for "agree", 3 points for "undecided", 2 points for "disagree" and 1 point for "strongly disagree". At the end of scoring, the respondent with the lowest score and the highest writing anxiety will get 26 points and the person with the highest score and the lowest writing anxiety will get 130 points. It can be said that the higher the points taken from the scale, the lower is the 
writing anxiety level and the lower the points taken from the scale, the higher is the writing anxiety level.

For this study, it was decided to use factor analysis to determine the validity of the writing anxiety scale. First, Kaiser-Meyer-Olkin (KMO) and Barlett tests were employed to understand whether the scale was suitable for factor analysis or not. In this context, the result of the KMO test measurement should be .60 and higher, the result of Barlett sphericity test should be statistically significant (Büyüköztürk, 2010: 126). KMO test result was .89 and Barlett sphericity test was significant $(\mathrm{P}<0.01)$ as a result of this study and it was concluded that exploratory factor analysis could be done to the scale. The limit value of item load was decided as .30 for every item in the scale. Statements that were in multiple items or items that were under the .30 limit value were removed from the scale.

Table 2

Results of exploratory factor analysis (rotated principal component analysis) of writing anxiety scale

\begin{tabular}{|c|c|c|c|c|c|}
\hline \multirow{2}{*}{$\begin{array}{l}\text { Item } \\
\text { No }\end{array}$} & \multirow{2}{*}{$\begin{array}{l}\text { Common Factor } \\
\text { Variance }\end{array}$} & \multirow{2}{*}{$\begin{array}{l}\text { Factor-1 } \\
\text { Load Value }\end{array}$} & \multicolumn{3}{|c|}{ Load Value after Rotation } \\
\hline & & & Factor-1 & Factor-2 & Factor-3 \\
\hline a7 & ,229 & ,361 &, 476 & & \\
\hline a13 & ,476 &, 621 &, 557 & & \\
\hline a16 & 445 &, 547 &, 624 & & \\
\hline a18 &, 591 & ,697 &, 732 & & \\
\hline a21 & 484 &, 597 &, 686 & & \\
\hline a24 & ,301 &, 417 &, 548 & & \\
\hline $\mathrm{a} 25$ & ,411 &, 610 & ,601 & & \\
\hline a26 &, 431 &, 622 &, 619 & & \\
\hline $\mathrm{a} 22$ &, 563 & ,668 &, 725 & & \\
\hline a2 & ,418 & 425 & & 21 & \\
\hline a6 &, 423 &,- 389 & & 17 & \\
\hline a11 & ,464 &, 504 & & 6 & \\
\hline a12 & 421 & ,402 & & 74 & \\
\hline a14 & ,398 &, 383 & & 24 & \\
\hline a23 &, 536 &, 445 & & 28 & \\
\hline a15 & ,689 &, 444 & & & ,731 \\
\hline a1 &, 595 &, 478 & & &, 712 \\
\hline
\end{tabular}

As a result of factor analysis applied to the "Writing Anxiety Scale", three factors were found. The first factor explains the $21,45 \%$ of the total variance related to the scale, the second factor $16,19 \%$ and the third factor $8,69 \%$. The explained total variance of the scale was determined 46,33\%. Büyüköztürk (2010: 124) states that explained variance in one factor scales should be $30 \%$ or higher and it should be higher in multifactor scale. According to the results obtained here, it can be concluded that the scale is valid.

After factor rotation, it is seen that the first factor of the scale is made up of nine items, the second factor six items and the third factor two items. Load values of items in the first factor change between 0,47 and 0,73 ; load values of items in the second factor change between 0,57 and 0,72 , and load values of items in the third factor change 
between 0,71 and 0,73 . Büyüköztürk (2010: 125) expresses that common factor variance of the items being close to 1 or above .66 is a good analysis but he also states that it is difficult to meet this in practice.

It is seen that the factor analysis of the scale adapted by Özbay and Zorbaz (2011) was done in two ways. An analysis based on the presumption that the scale has two factors in the first analysis. In the second analysis, criterion factor load value that provides basis for deciding on item selection and suitability of an item was decided .30 or above. Since exploratory percentage of total variance of the structure resulting from the second factor analysis is above $50 \%$, the results of this analysis was found to be more suitable to use. A structure with four factors that explain the $53 \%$ of the total variance and that have eigenvalue over 1 was found out during the factor analysis done by removing some of the items $(6,7,8,11$ and 21) after applying varimax, one of the rotation techniques of Principal Component Analysis technique.

Cronbach's alpha reliability statistics was conducted to determine the writing anxiety scale's reliability in this study. According to the statistics done, Cronbach's alpha value of the first factor was .87 , value of the second factor was .78 , value of the third factor was .68 and Cronbach's alpha value of the total scale was .73. Tezbaşaran (1997: 47) mentions that for a Likert-type scale's reliability coefficient should be as close to 1 as possible. According to these results, it can be said that the scale's reliability is high.

Cronbach's alpha coefficient of the scale adapted by Özbay and Zorbaz (2011) was calculated and Cronbach's alpha value was calculated as .901. The item-total test correlations of the scale was between .33 and .67. The scale's internal consistency coefficient for the first factor was .841 , for the second factor was .799 , for the third factor was .689 and for the fourth factor was .681 . According to these results, the scale is a reliable measurement tool.

In the study, "Writing Disposition Scale", developed by Piazza and Siebert (2008) and adapted into Turkish by İşeri and Ünal (2019), was administered to determine elementary school students' writing dispositions.

The scale is made up of three sub-dimensions: confidence, persistence and passion. Each sub-dimension has 31 items and the scale is made up of 93 items in total. Five-point Likert-type scale is developed from "strongly agree" (5 points) to "strongly disagree" (1 point) and the negative items is reverse scored. The lowest score is 93 and the highest score is 465 . At the end of the validity and reliability studies done for the original scale, the latest scale was made up of 11 items. The lowest score that can be taken from the latest version is 11 and the highest score is 55 . While the high scores obtained from the scale means positive writing disposition, the lower scores means negative writing disposition.

For this study, it was decided to use factor analysis to determine the validity of the writing disposition scale. First, Kaiser-Meyer-Olkin (KMO) and Barlett tests were employed to understand whether the scale was suitable for factor analysis or not. In this context the KMO test measurement should be .60 and higher, the result of Barlett sphericity test should be statistically significant (Büyüköztürk, 2010: 126). KMO test 
result was .94 and Barlett sphericity test was significant $(\mathrm{P}<0.01)$ as a result of this study and it was concluded that exploratory factor analysis could be done to the scale.

Table 3

Results of exploratory factor analysis (rotated principal component analysis) of writing disposition scale

\begin{tabular}{|c|c|c|c|c|c|}
\hline \multirow{2}{*}{ Item No } & \multirow{2}{*}{$\begin{array}{l}\text { Common Factor } \\
\text { Variance }\end{array}$} & \multirow{2}{*}{$\begin{array}{l}\text { Factor-1 } \\
\text { Load value }\end{array}$} & \multicolumn{3}{|c|}{ Load Value after Rotation } \\
\hline & & & Factor-1 & Factor-2 & Factor-3 \\
\hline d1 & ,583 & ,605 & &, 705 & \\
\hline $\mathrm{d} 2$ & ,593 &,- 477 & &,- 756 & \\
\hline $\mathrm{d} 3$ & ,507 &,- 504 & &,- 674 & \\
\hline $\mathrm{d} 4$ & ,575 & ,516 & & ,739 & \\
\hline $\mathrm{d} 5$ & ,588 & ,581 & & ,724 & \\
\hline d6 & ,625 & ,566 & & ,757 & \\
\hline $\mathrm{d} 7$ & ,463 & & & & ,672 \\
\hline d9 & ,530 & & & & ,719 \\
\hline $\mathrm{d} 10$ & ,654 & & & & ,803 \\
\hline $\mathrm{d} 11$ & ,428 & ,504 & ,684 & & ,522 \\
\hline $\mathrm{d} 12$ & ,580 & ,728 & ,753 & & \\
\hline $\mathrm{d} 13$ & ,600 & ,726 & ,754 & & \\
\hline $\mathrm{d} 14$ & ,624 & ,728 & ,721 & & \\
\hline $\mathrm{d} 15$ & ,604 & ,741 & ,797 & & \\
\hline $\mathrm{d} 16$ & ,683 & ,775 & ,752 & & \\
\hline $\mathrm{d} 17$ & ,601 & ,701 & ,674 & & \\
\hline $\mathrm{d} 18$ & ,544 & ,711 & ,626 & & \\
\hline d19 & ,505 & ,673 & ,735 & & \\
\hline $\mathrm{d} 20$ & ,622 & ,743 & ,770 & & \\
\hline $\mathrm{d} 21$ & ,637 & ,755 &, 713 & & \\
\hline
\end{tabular}

As a result of factor analysis applied to the "Writing Disposition Scale", three factors were obtained. The first factor explains the $10,56 \%$ of the total variance related to the scale, the second factor $17,56 \%$ and the third factor $8,69 \%$. The explained total variance of the scale was determined $57,56 \%$. Büyüköztürk (2010: 124) states that explained variance in one factor scales should be $30 \%$ or higher and it should be higher in multifactor scale. According to the results obtained here, it can be concluded that the scale is valid.

After factor rotation, it is seen that the first factor of the scale is made up of 11 items, the second factor is made up of six items and the third factor is made up of four items. Load values of items in the first factor vary between 0,62 and 0,79 ; load values of items in the second factor vary between 0,67 and 0,75 , and load values of items in the third factor vary between 0,52 and 0,80 . Büyüköztürk (2010: 125) states that common factor variance of the items being close to 1 or above .66 is a good analysis but he also states that it is difficult to meet this in practice.

Three factors were obtained from adapted version of the "Writing Disposition Scale" (İşeri and Ünal, 2010). The first, second and third factors explain the 30,08\%, 8,45\% and $7,73 \%$ of the total variance related to the scale respectively while the total of the scale's factor dimensions explain the $46,26 \%$ of the scale. After factor rotation, it is seen that the first factor of the scale is made up of 11 items, the second factor six items and 
the third factor four items. Load values of items in the first factor vary between 0,601 and 0,702; load values of items in the second factor change between 0,561 and 0,668, and load values of items in the third factor change between 0,632 and 0,748.

Cronbach's alpha reliability statistics were conducted to determine the writing disposition scale's reliability in this study. According to the statistics done, Cronbach's alpha value of the first factor was .93, value of the second factor was .89 , value of the third factor was .73 and Cronbach's alpha value of the total scale was .88. Tezbaşaran (1997: 47) mentions that for a Likert-type scale's reliability, coefficient should be as close to 1 as possible. According to these results, it can be said that the scale's reliability is high.

Cronbach's alpha coefficient of the scale adapted by İşeri and Ünal (2010) was calculated and Cronbach's alpha value was found to be .874 for the total scale, .882 for the passion sub-dimension, .734 for the confidence sub-dimension and .639 for the persistence. While the reliability of the scale is high for the passion and confidence subdimensions, it is at an acceptable level for the persistency sub-dimension.

The data collected in this study have been transferred to a computer and regression, simple regression and multiple regression analysis were used for the statistical analysis of the data.

\section{FINDINGS}

Findings and interpretations regarding the problem sentence and sub-problems are presented in this section of the study. The findings regarding the main question of the study, "Is writing disposition a significant predictor of writing anxiety?" are given in Table 4.

Table 4

Regression analysis results regarding prediction of writing anxiety based on writing disposition

\begin{tabular}{llllllll}
\hline Variables & $B$ & $\begin{array}{l}\text { Standard } \\
\text { Error }_{B}\end{array}$ & $\beta$ & $t$ & $p$ & $\begin{array}{l}\text { Zero } \\
\text { Order } r\end{array}$ & Partial r \\
\hline Fixed & 4,202 &, 086 & & 48,983 &, 000 & & \\
Writing Anxiety &,- 348 &, 032 &,- 348 & $-10,857$ &, 000 &,- 348 &,- 348 \\
\hline
\end{tabular}

When Table 4 is examined, writing disposition is found to be a significant predictor of writing anxiety $(\mathrm{R}=0.35, \mathrm{R} 2=0.12 ; \mathrm{F}(1-858)=117.882, \mathrm{p}<.05)$. When the regression analysis table is examined, it can be stated that $12 \%$ of the total variance regarding writing anxiety is explained by writing disposition. According to standardized regression coefficient $(\beta)$, it can be said that an increase in writing disposition will lead to decrease in writing anxiety.

\subsection{Findings Regarding Students' Genders and Grade Level Predicting Writing Disposition}

The findings regarding the first sub-title of the study, "Are students' grade levels and genders significant predictors of writing disposition?", are given in Table 5. 
Table 5

Regression analysis results regarding prediction of writing disposition based on students' grade levels and genders

\begin{tabular}{llllllll}
\hline Variables & $B$ & $\begin{array}{l}\text { Standard } \\
\text { Error }_{B}\end{array}$ & $\beta$ & $t$ & $p$ & $\begin{array}{l}\text { Zero } \\
\text { Order } r\end{array}$ & $\begin{array}{l}\text { Partial } \\
r\end{array}$ \\
\hline Fixed & 3,987 &, 081 & & 49,043 &, 000 & & \\
Grade &,- 081 &, 024 &,- 108 & $-3,317$ &, 001 &,- 105 &,- 113 \\
Gender &,- 363 &, 042 &,- 279 & $-8,554$ &, 000 &,- 278 &,- 280 \\
\hline
\end{tabular}

When Table 5 is examined, students' grade levels and genders are found to be significant predictors of writing disposition $\left(\mathrm{R}=0.298, \mathrm{R}^{2}=0.089 ; \mathrm{F}_{(2-857)}=41.818\right.$, $\mathrm{p}<.05)$. When the regression analysis table is examined, it can be stated that $0.9 \%$ of the total variance regarding writing disposition is explained by gender and grade variables. According to standardized regression coefficient $(\beta)$, predictor variables' relative significance order on writing disposition is gender and grade. When the t-test results regarding the significance of regression coefficients are examined, it is seen that both the grade level and the gender are important predictors of writing disposition.

According to regression analysis, regression equation regarding prediction of writing dispositions can be stated as "Writing Disposition = 3, 978-0,081 GRADE-0,363 GENDER". The study conducted by Tüfekçioğlu (2010) also reached the conclusion that students' genders are related to their writing dispositions.

\subsection{Findings Regarding Students' Genders and Grade Level Predicting Writing Anxiety}

The findings regarding the second sub-title of the study, "Are students' grade levels and genders significant predictors of writing anxiety?" are given in Table 6.

Table 6

Regression analysis results regarding prediction of writing disposition based on students' grade levels and genders

\begin{tabular}{llllllll}
\hline Variables & $B$ & $\begin{array}{l}\text { Standard } \\
\text { Error }_{B}\end{array}$ & $\beta$ & $t$ & $p$ & $\begin{array}{l}\text { Zero } \\
\text { Order } r\end{array}$ & Partial $r$ \\
\hline Fixed & 1,801 &, 079 & & 22,690 &, 000 & & \\
Grade &, 071 &, 024 &, 096 & 2,996 &, 003 &, 092 &, 102 \\
Gender &, 446 &, 041 &, 344 & 10,788 &, 000 &, 343 &, 346 \\
\hline
\end{tabular}

When Table 6 is examined, students' grade levels and genders are found to be significant predictors of writing anxiety $\left(\mathrm{R}=0.356, \mathrm{R}^{2}=0.127 ; \mathrm{F}_{(2-857)}=62.372, \mathrm{p}<.05\right)$. When the regression analysis table is examined, it can be stated that $13 \%$ of the total variance regarding writing anxiety is explained by genders and grade variables. According to standardized regression coefficient $(\beta)$, predictor variables' relative significance order on writing anxiety is gender and grade. When the t-test results regarding the significance of regression coefficients are examined, it is seen that both grade level and the gender are important predictors of writing anxiety. 
According to regression analysis, regression equation regarding prediction of writing anxiety can be stated as "Writing Anxiety = 1,801+0,071 GRADE+0,0446 GENDER". The studies done by Zorbaz (2010) and Karakoç Öztürk (2012) also reached the conclusion that students' genders and grade levels have effects on their writing anxiety. While Zorbaz (2010) found that males' writing anxiety is higher compared to females and as the grade levels increase the writing anxiety increases, Karakoç Öztürk found the opposite in terms of grade levels.

\section{DISCUSSION}

According to regression analysis result regarding prediction of writing anxiety based on writing disposition it can be said that writing disposition is a significant predictor of writing anxiety. In this case, it can be said that the increase in writing disposition will decrease writing anxiety.

The result of regression analysis result regarding students' genders and grade level predicting writing disposition show that students' genders and grade levels are significant predictors of writing disposition. Also, the t-test results regarding the significance of regression coefficients show that both the grade level and the gender are important predictors of writing disposition.

The result of regression analysis result regarding students' genders and grade level predicting writing anxiety show that students' genders and grade levels are significant predictors of writing anxiety. Also, the t-test results regarding the significance of regression coefficients show that both grade level and gender are important predictors of writing anxiety.

\section{Recommendations}

The results of the study revealed that writing disposition is a meaningful predictor of writing anxiety; also, grade and gender level of the students are meaningful predictors of writing anxiety and dispositions. It is concluded that there is an inverse proportion between writing disposition and writing anxiety. That is, when writing disposition increases, writing anxiety decreases. Therefore, in order to create a strong writing disposition for students, it is recommended that required education environment (inside outside of school) should be provided. This study, which aims to predict writing anxiety and writing dispositions, was conducted with students at grades 6,7 and 8. Similar studies can be conducted to reinforce the study results, support or put different dimensions of the study.

\section{REFERENCES}

Aktaş, Ş. \& Gündüz, O. (2004). Yazılı ve Sözlü Anlatım - Kompozisyon Sanatı [Written and Oral Expression - The Art of Composition]. Ankara: Akçağ Yayıncılık.

Arıcı, A. F. \& Ungan, S. (2008). İlköğretim ikinci kademe öğrencilerinin yazılı anlatım çalışmalarının bazı yönlerden değerlendirilmesi [An evaluation of secondary school students' writing mistakes with respect to some points]. Dumlupinar Üniversitesi Sosyal Bilimler Dergisi, 20, 317-327. Retrieved from 
http://birimler.dpu.edu.tr/app/views/panel/ckfinder/userfiles/17/files/DERG_/20/315327.pdf

Baş, G. \& Şahin, C. (2012). İlköğretim 6. 7. ve 8. sınıf öğrencilerinin okuma tutumları ve yazma eğilimleri ile türkçe dersindeki akademik başarıları arasındaki ilişki [Correlation amongst reading attitudes, writing dispositions and academic success of elementary $6^{\text {th }}, 7^{\text {th }}$ and $8^{\text {th }}$ grade students in turkish course]. Turkish Studies, 7(3), 555$572 . \quad$ Retrieved from http://www.turkishstudies.net/Makaleler/1505080312_30Ba\%C5\%9F\%20G\%C3\%B6kh an-Cemil\%20\%C5\%9Eahin_S-555-572.pdf

Brand, A. G. \& Powell, J. L. (1986). Emotions and the writing process: A description of apprentice writers. The Journal of Educational Research, 79(5), 280-285. Retrieved from http://www.tandfonline.com/doi/abs/10.1080/00220671.1986.10885692

Büyüköztürk, S. (2010). Sosyal Bilimler İçin Veri Analizi El Kitabı [Data Analysis Handbook for the Social Sciences]. Ankara: Pegem A.

Daly, J. A. \& Miller, M. D. (1975a). The empirical development of an instrument to measure writing apprehension. Research in the Teaching of English, 9, 242-248. Retrieved from http://www.jstor.org/stable/pdf/40170632.pdf?acceptTC=true

Daly, J. A. \& Miller, M. D. (1975b). Apprehension of writing as a predictor of message intensity. The Journal of Psychology, 89(2), 175-177. Retrieved from http://www.tandfonline.com/doi/abs/10.1080/00223980.1975.9915748

Daly, J. A. \& Wilson, D. A. (1983). Writing Apprehension, self-esteem, and personality. Research in the Teaching of English, 17, 327-341. Retrieved from http://www.jstor.org/stable/pdf/40170968.pdf

Da Ros-Voseles, D. \& Fowler-Haughey, S. (2007). Why children's dispositions should matter to all teachers. Young Children: Beyond the Journal, September, 2007. Retrieved from https://www.naeyc.org/files/yc/file/200709/DaRos-Voseles.pdf

Göçer, A. (2011). Yazma Çalışmalarını Değerlendirme [Assessment of Writing Studies], Yazma Eğitimi [Writing Education]. Murat Özbay (Ed.), (p. 199-240), Ankara: Pegem A Yayıncilık.

Güneş, F. (2007). Türkçe Öğretimi ve Zihinsel Yapılandırma [Turkish Education and Mental Configuration]. Ankara: Nobel Yayıncılik.

Güneş, F. (2013). Türkçe Öğretimi Yaklaşımlar ve Modeller. Ankara: Pegem A Yayıncilik.

Hidi, S. \& Boscolo, P. (2006). Motivation and Writing. Handbook of Writing Research. C. A. MacArthur, S. Graham \& J. Fitzgerald (Ed.), NewYork: Guilford Press.

İşeri, K. \& Ünal, E. (2010). Yazma eğilimi ölçeğinin Türkçeye uyarlanması [The adaptation of writing disposition scale into Turkish]. Eğitim ve Bilim Dergisi, 35(155), 
104-117.

Retrieved

from

http://egitimvebilim.ted.org.tr/index.php/EB/article/view/564/52

İşeri, K. \& Ünal, E. (2012). Türkçe öğretmen adaylarının yazma kaygı durumlarının çeşitli değişkenler açısından incelenmesi [Analyzing the Turkish teacher candidates' writing anxiety situations in terms of several variables]. Mersin Üniversitesi Eğitim Fakültesi Dergisi, 8(2), 67-76. Retrieved from http://dergipark.ulakbim.gov.tr/mersinefd/article/view/1002000182/1002000193

Karakaya, İ. \& Ülper, H. (2011). Yazma kaygısı ölçeğinin geliştirilmesi ve yazma kaygısının çeşitli değişkenlere göre incelenmesi [Developing a writing anxiety scale and examining writing anxiety based on various variables]. Kuram ve Uygulamada Eğitim Bilimleri Dergisi, 11(2), 691-707. Retrieved from https://edam.com.tr/kuyeb/pdf/tr/34d378c8b7c67b08105f19dd76bda4aayaTAM.pdf

Karasar, N. (1999). Bilimsel Araştırma Yöntemi: Kavramlar. İlkeler, Teknikler [Research Methods : Concepts . Principles, Techniques]. Ankara: Nobel Yayınevi.

Karakoç Öztürk, B. (2012). İlköğretim ikinci kademe öğrencilerinin yazma kaygılarının çeşitli değişkenler açısından incelenmesi [The study of writing anxiety of the elementary school students in terms of various variables]. Çukurova Üniversitesi Sosyal Bilimler Enstitüsü Dergisi, 21(2), 59-72. Retrieved from http://dergipark.ulakbim.gov.tr/cusosbil/article/view/5000001588/5000002279

Karatay, H. (2011). Süreç Temelli Yazma Modelleri: Planlı Yazma ve Değerlendirme [Based Writing Process Models: Planned Writing and Evaluation]. Yazma Eğitimi [Writing Education]. Murat Özbay (Ed.), (p. 21-43). Ankara: Pegem A Yayıncılık.

Katz, L. G. \& Raths, J. D. (1985). Dispositions as goals for teacher education. Teaching and Teacher Education, 1(4), 301-307.

Katz, L. G. (1993). Dispositions: Definitions and Implications for Early Childhood Practices. Perspectives from ERIC/EECE: A Monograph Series, 4. (ERIC Document Reproduction Service No. ED360104). Retrieved from http://files.eric.ed.gov/fulltext/ED360104.pdf

Maltepe, S. (2006). Yaratıcı yazma yaklaşımı açısından Türkçe derslerindeki yazma süreçlerinin ve ürünlerinin değerlendirilmesi [Evaluation of writing processes and products in Turkish courses based on creative writing approach] (Unpublished doctoral dissertation). Ankara Üniversitesi Sosyal Bilimler Enstitüsü, Ankara. Retrieved from http://acikarsiv.ankara.edu.tr/browse/1533/2162.pdf?show

McClenny, C. S. (2010). A disposition to write: Relationships with writing performance (Unpublished Master Thesis). The Florida State University, College of Education, Florida. Retrieved from http://diginole.lib.fsu.edu/islandora/object/fsu:180879/datastream/PDF/view 
McLeod, S. (1987). Some thoughts about feelings: The affective domain and the writing process. College Composition and Communication, 38(4), 426-435. Retrieved from http://www.jstor.org/stable/pdf/357635.pdf

Özbay, M. (2000). İlköğretim Okulu Öğrencilerinin Yazılı Anlatım Becerileri (Alan Araştırması) [Writing Skills of Elementary School Students (Field Research )]. Ankara: Bizim Büro Basımevi.

Özbay, M. (2006). Özel Öğretim Yöntemleri I [Special Teaching Methods I]. Ankara: Öncü Kitap.

Özbay, M. (2011). Anlama Teknikleri I: Okuma Eğitimi [Comprehension Techniques I: Reading Education]. Ankara: Öncü Kitap.

Özbay, M. \& Zorbaz, K. Z. (2011). Daly ve Miller'in yazma kaygısı ölçeğinin Türkçeye uyarlanmas1 [Adaptation of Daly-Miller's writing apprehension test to Turkish]. Mustafa Kemal Üniversitesi Sosyal Bilimler Enstitüsü Dergisi, 8(16), 33-48. Retrieved from http://sbed.mku.edu.tr/article/view/1038000226/1038000222

Piazza, C. L. \& Siebert, C. F. (2008). Development and validation of a writing dispositions scale for elementary and middle school students. The Journal of Educational Research, 101(5), 275-285. Retrieved from http://www.tandfonline.com/doi/pdf/10.3200/JOER.101.5.275-286

Reeves, L. L. (1997). Minimizing writing apprehension in the learner-centered classroom. The English Journal, 86(6), 38-45. Retrieved from http://www.learner.org/workshops/middlewriting/images/pdf/W1ReadMinimizing.PDF

Sever, S. (2004). Türkçe Öğretimi ve Tam Öğrenme [Turkish Education and Mastery Learning]. Ankara: Anı Yayıncılık.

Sing, D. \& Stoloff, D. (2007). Measuring Teacher Dispositions. Paper presented at the National Fifth Annual Symposium on Educator Dispositions (Earlenger, KY, November, 2007).

Smith, R. L., Hurst, J. \& Skarbek, D. (Ed.). (2005). The passion of teaching: Dispositions in the schools. Maryland: R\&L Education.

Smagorinsky, P., \& Daigle, E. A. (2012). The role of affect in students' writing for school. In E. Grigorenko, E. Mambrino, \& D. Preiss (Eds.), Handbook of writing: A mosaic of perspectives and views (pp. 293-307). New York: Psychology Press.

Tezbaşaran, A. A. (1997). Likert Tipi Ölçek Geliştirme Kılavuzu [Likert Scale Development Guide]. Ankara: Türk Psikologlar Derneği Yayınları, 19-51.

Thornton, H. (2006). Dispositions in action: Do dispositions make a difference in practice?.Teacher Education Quarterly, 33(2), 53-68. Retrieved from http://files.eric.ed.gov/fulltext/EJ795207.pdf

Tighe, M. A. (1987). Reducing Writing Apprehension in English Classes. Paper presented at Annual Meeting of the National Council of Teachers of English Spring 
Conference, March 26-28, 1987, Louisville. Retrieved from http://files.eric.ed.gov/fulltext/ED281196.pdf

Tiryaki, E. N. (2012). Üniversite öğrencilerinin yazma kaygısının çeşitli değişkenler açısından belirlenmesi [Determining writing anxieties of university students' from different variables]. Dil ve Edebiyat Eğitimi Dergisi, 1(1), 14-21. Retrieved from http://jllesite.org/sayilar/1(1)/2\%20Esra\%20Nur\%20Tiryaki.pdf

Tüfekçioğlu, B. (2010). Yazma becerisinin bazı değişkenler açısından incelenmesi [Examination of writing skill in terms of some variables]. Dil Dergisi, 149, 30-45. Retrieved from http://dergiler.ankara.edu.tr/dergiler/27/1606/17290.pdf

Uçgun, D. (2011). İlköğretim Programlarında Yazma Eğitimi [Writing in the Elementary Education Program]. Yazma Eğitimi [Writing Education]. Murat Özbay (Ed.), (p. 1-19). Ankara: Pegem A Yayıncilik.

Ungan, S. (2007). Yazma becerisinin geliştirilmesi ve önemi [Develepment of and importance of writing skills]. Erciyes Üniversitesi Sosyal Bilimler Enstitüsü Dergisi, 2(23), 461-472. Retrieved from http://sbedergi.erciyes.edu.tr/sayi_23/sayi_23.htm

Yaman, H. (2010). Türk öğrencilerinin yazma kaygısı: Ölçek geliştirme ve çeşitli değişkenler açısından yordama çalışması [Writing anxiety of Turkish students: Scale development and the working procedures in terms of various variables]. International Online Journal of Educational Sciences, 2(1), 267-289. Retrieved from http://www.iojes.net//userfiles/Article/IOJES_185.pdf

Yaman, H. \& Karaarslan, F. (2013). Yazma becerisinin geliştirilmesinde beyin firtınası tekniğinin etkililiği üzerine nitel bir araştırma [A qualitative research about efficiency of brain storming technique on improvement of writing skill]. International Journal of Social Science, 6(6), 1195-1223. Retrieved from http://www.jasstudies.com/Makaleler/1134715719_58YamanHavva-vd-1195-1223.pdf

Yancey, K. B. (2009). Writing in the 21st Century. National Council of Teachers of English. Retrieved from http://www.ncte.org/library/NCTEFiles/Press/Yancey_final.pdf

Zorbaz, K. Z. (2010). Illköğretim okulu öğrencilerinin yazma kaygl ve tutukluğunun yazıll anlatım becerileriyle ilişkisi [The relationship between middle school student's writing apprehension and blocking with their written expression skills] (Unpublished doctoral dissertation). Gazi Üniversitesi Eğitim Bilimleri Enstitüsü, Ankara. 


\section{Turkish Abstract \\ Altıncı, Yedinci ve Sekizinci Sınıf Öğrencilerinin Yazma Kaygısı ve Yazma Eğilimlerinin Karşılaştırılması}

Bu çalışmanın amacı altıncı, yedinci ve sekizinci sınıf öğrencilerinin yazma endișeleri ve yazma kaygılarını tanımlayarak birbirlerine ne ölçüde üstün olduklarını incelemektir. Araştırmanın temeli, yazma eğiliminin yazma endişesini tanımlamada önemli bir yordama aracı olup olmadığını ve ögrenci sınıf derecesinin yine yazma eğilimi ve yazma endişesini tanımlamada önemli bir yordama aracı olup olmadığını belirlemektir. Araştırma, anket yöntemine göre tasarlanmıştır. Çalıșma grubu, basit örnekleme yöntemiyle seçilmiş Sivas Şarkışla'daki 860 altıncı, yedinci ve sekizinci sınıf öğrencisinden oluşmaktadır. Çalışma grubunun yazma endişe düzeyini belirlemeye yönelik "Yazma Endişesi Skalası" Türkçe'ye Özbay ve Zorba (2011) tarafından uyarlanırken; İşeri ve Ünal (2010) tarafindan Türkçe'ye uyarlanan "Yazma Eğilimi Skalası" yazma eğilim düzeyini tanımlamak için kullanılmıştır. Çalışmanın sonunda yazma eğiliminin yazma endişesini yordamada önemli olduğu ve öğrencilerin sınıf dereceleri ve cinsiyetin yazma eğilimi ve yazma endişesini yordamada önemli bir araç olduğu bulunmuştur. Öğrencilerde güçlü bir yazma eğilimi yaratmak için eğitim ortamını önemli olduğu tavsiye edilmiştir. Ayrıca benzer çalışmalar farklı boyutlarda yürütülebilir.

Anahtar Kelimeler: yazma kaygısı, yazma eğilimi, yazma becerisi, ilköğretim, yazma

\section{French Abstract}

La comparaison d'Écrire l'Anxiété et Écrire les Dispositions d'Étudiants de Quatrième et Sixième, Septième

Le but de cette étude est de déterminer l'anxiété d'écriture des étudiants de quatrième et sixième, septième et des dispositions et examiner dans quelle mesure ils se prévoient. La base de cette étude est de déterminer si l'écriture de la disposition est le prophète significatif d'écrire l'anxiété ou pas et si les niveaux de niveau et des genres des étudiants sont le prophète significatif d'écrire l'anxiété et des dispositions ou non. La recherche a été conçue selon le modèle d'enquête. Le groupe d'étude, choisi par la méthode d'échantillonnage simple, est composé de 860 étudiants étudiant à 6ème, 7ème et des 4èmes dans les écoles primaires de Quartier Sarkisla, Sivas. Tandis que "l'Écriture de l'Échelle d'Anxiété", adapté dans turc par Özbay et Zorbay (2011), a été administrée pour déterminer le niveau d'anxiété d'écriture du groupe d'étude, "l'Écriture de l'Échelle de Disposition", adapté dans turc par Iseri et Ünal (2010), a été utilisée pour déterminer le niveau de disposition d'écriture. À la fin de l'étude, il a été trouvé que l'écriture de la disposition est un prophète significatif d'écrire l'anxiété et les niveaux de niveau et les genres des étudiants sont les prophètes significatifs d'écrire l'anxiété et des dispositions. On recommande à un environnement d'enseignement(éducation) de créer une disposition d'écriture forte pour des étudiants. Aussi, des études semblables sur les dimensions différentes de la question peuvent être conduites.

Mots Clés: en écrivant anxiété, écrivant disposition, écrivant compétence, école primaire, écriture 


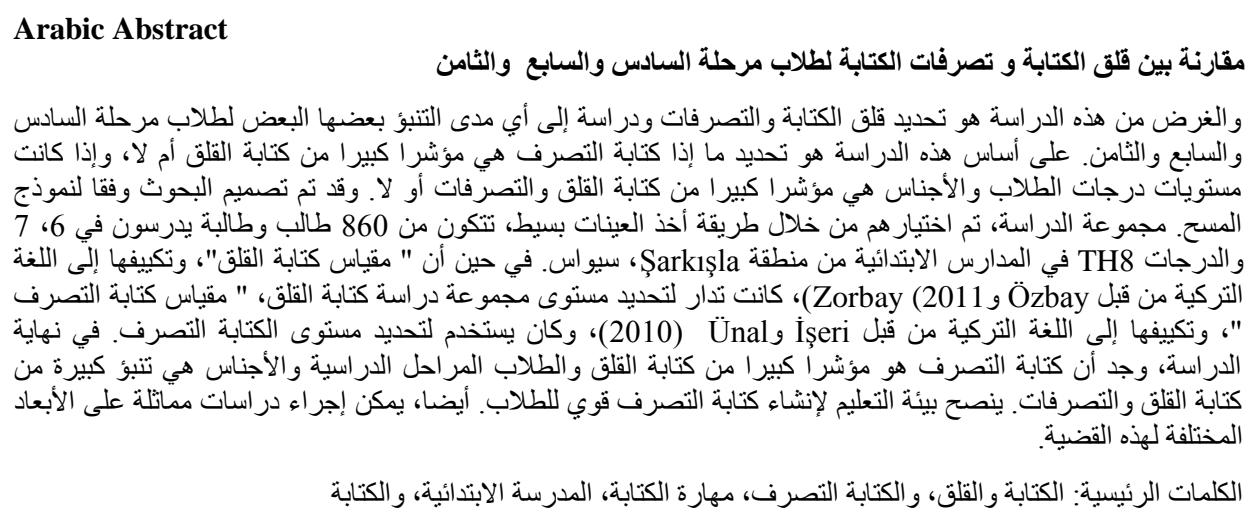

\section{German Abstract}

Vergleich der Schreiben Angst und Schreiben Dispositionen der Sechsten, Siebten und Achten Klasse Studenten

Der Zweck dieser Studie ist es, sechste, siebte und achte Klasse Studenten schriftlich Angst und Dispositionen zu bestimmen und zu prüfen, inwieweit sie einander vorhersagen. Die Grundlage dieser Studie ist zu bestimmen, ob Schreiben Disposition der signifikante Prädiktor des Schreibens Angst ist oder nicht und ob Schüler Grade Ebenen und Geschlechter sind signifikante Vorhersage des Schreibens Angst und Dispositionen oder nicht. Die Forschung wurde nach Umfrage Modell entworfen. Die durch einfache Stichprobenmethode ausgewählte Studiengruppe besteht aus 860 Studenten, die in den Grundschulen des Bezirks Şarkışla, Sivas, 6., 7. und 8. Klasse studieren. Während die von Özbay und Zorbay (2011) in die türkische Sprache geschriebene " Schreiben Angst scale" verabreicht wurde, wurde die Schriftstudie " Schreiben Disposition Scale" der Studiengruppe, die von İşeri und Ünal (2010) in das Türkische angepasst wurde, bestimmt Der Schreibanordnungsebene. Am Ende der Studie wurde festgestellt, dass Schreiben Disposition ein signifikanter Prädiktor des Schreibens Angst und Schüler Grade Ebenen und Geschlechter sind signifikante Prädiktoren des Schreibens Angst und Dispositionen. Ein Bildungsumfeld, um eine starke schriftliche Disposition für Studenten zu schaffen, wird empfohlen. Auch können ähnliche Studien zu verschiedenen Dimensionen des Problems durchgeführt werden.

Schlüsselwörter: schreiben angst, schreiben disposition, schriftlich geschick, grundschule, schriftlich 


\section{Malaysian Abstract \\ Perbandingan Kebimbangan Penulisan dan Pelupusan Penulisan Pelajar Gred Enam, Tujuh dan Lapan}

Tujuan kajian ini adalah untuk menentukan kebimbangan penulisan dan pelupusan dalam kalangan pelajar gred keenam, ketujuh dan kelapan. Selanjutnya untuk memeriksa sejauh mana mereka meramalkan satu sama lain. Asas kajian ini adalah untuk menentukan sama ada menulis pelupusan adalah peramal yang signifikan terhadap kebimbangan menulis atau tidak dan sama ada tahap gred dan jantina pelajar adalah peramal yang signifikan kebimbangan menulis dan pelupusan atau tidak. Kajian ini direka mengikut model kajian. Kumpulan kajian, yang dipilih melalui kaedah persampelan mudah, terdiri daripada 860 pelajar yang belajar di 6, 7 dan gred 8 di sekolah-sekolah rendah di Daerah Şarkışla, Sivas. Walaupun "Menulis Skala Kebimbangan", disesuaikan ke dalam Turkish oleh Ozbay dan Zorbay (2011), telah ditadbir untuk menentukan tahap kumpulan kajian yang bertulis kebimbangan, "Skala Penulisan Pelupusan", disesuaikan ke dalam Turkish oleh İşeri dan Ünal (2010), telah digunakan untuk menentukan tahap bertulis pelupusan. Pada akhir kajian ini, didapati bahawa menulis pelupusan adalah peramal yang signifikan kebimbangan penulisan tahap gred dan jantina adalah peramal bererti kebimbangan menulis dan pelupusan. Persekitaran pendidikan untuk mewujudkan pelupusan bertulis kuat untuk pelajar adalah disyorkan. Selain itu, kajian sama di dimensi yang berbeza daripada isu itu boleh dilakukan.

Kata Kunci: kebimbangan penulisan, pelupusan penulisan, kebimbangan, menulis kebimbangan, menulis

\section{Russian Abstract \\ Шестом, Седьмом и Восьмом Классах Написаний Тревоги и Написание Диспозиции Сравнение}

Целью данного исследования является определение шестой, седьмой и учащихся восьмого класса написание тревоги и диспозиции и исследовать к какие степени они предсказывают друг друга. Основой данного исследования является определить, является ли писать диспозиция является значимым предиктором пишущего тревоги или нет и является ли уровень класса студентов и пол являются значимым предиктором написания тревожности и предрасположенности или нет. Исследования был разработан в соответствии с обследование моделью. Исследовательская группа, выбирается через помощью простого метода отбора проб, состоит из 860 студентов обучающихся на 6,7 и 8 классов в начальных школах Şarkışla района, Сивас. В то время как "Письменная шкала тревожности”, адаптированный на турецкий язык по Ozbay и Zorbay (2011), назначался для определения уровня тревожности написания исследовательской группы, "Письменная Планировка Масштаб”, адаптирована в турецком к İșeri и Ünal (2010), был использован для определения уровня распоряжения письма. В конце исследования, было установлено, что написание диспозиция значимым предиктором написания тревоги и уровней ранга студентов и полов являются значимыми прогностическими факторами написания тревоги и диспозиции. Окружающая образования чтобы создать сильную письмо диспозиция для студентов рекомендуется. Также, аналогичные исследовани различным размеры проблемы может быть проведено.

Ключевые Слова: записывание беспокойство, написание диспозиция, навыки письма, начальная школа, письмо 